\title{
Modelling the Composite Competitiveness Index of the Knowledge-based Society
}

\author{
Andrea Katić ${ }^{1}$, Tibor Kiš ${ }^{2}$, Ilija Ćosić ${ }^{3}$, Simonida Vukadinović ${ }^{4}$, \\ Tinde Dobrodolac Šeregelj ${ }^{5}$
}

${ }^{1}$ University of Novi Sad, Faculty of Technical Sciences, Trg Dositeja Obradovića 6, 21000 Novi Sad/ EDUCONS University, Vojvode Putnika 87, 21208 Sremska Kamenica, Serbia, e-mail: andrea.katic@educons.edu.rs

${ }^{2}$ University of Novi Sad, Faculty of Economics in Subotica, Segedinski put 9-11, 24000 Subotica, Serbia, e-mail: tkis@ef.uns.ac.rs

${ }^{3}$ University of Novi Sad, Faculty of Technical Sciences, Trg Dositeja Obradovića 6, 21000 Novi Sad, Serbia, e-mail: ilijac@uns.ac.rs

${ }^{4}$ EDUCONS University, Vojvode Putnika 87, 21208 Sremska Kamenica, Serbia, e-mail: simonida.vukadinovic@educons.edu.rs

${ }^{5}$ University of Novi Sad, Faculty of Economics in Subotica, Segedinski put 9-11, 24000 Subotica, Serbia, e-mail: tinde@ef.uns.ac.rs

Abstract: In the era of globalization of world markets, movement of the European Union toward the knowledge-based society, and Serbia's EU accession process, competition has become one of the most important characteristics of successful development and achievement of these objectives. The existing competitiveness indices are discussed in this study, and it has been found that they do not reflect the position of transition countries and Serbia appropriately. A great impact of the quality indicators on Serbian ranking was determined based on the analysis of the existing studies. A new, original index is therefore proposed - the Competitiveness Index of the Knowledge-Based Society. The index is applied to 18 territorial units, including the EU and the Western Balkan countries, Serbia, and Vojvodina as a European region. The new model set out in this article provides a more realistic and objective picture of the state of Serbia and the Western Balkans as regards the competitiveness of knowledge. In other words, the new competitiveness model of knowledge-based society provides a better monitoring of the development of the Republic of Serbia and the Western Balkans on their way towards development of knowledge society. The results are analyzed and discussed.

Keywords: competitiveness indices; knowledge society; knowledge as a criterion for competitiveness; Serbia 


\section{Introduction}

The European Union has set the development towards the knowledge-based society as its central objective to achieve competitive advantage in global competition. The Western Balkan countries, including Serbia, have set the EU accession as their strategic goal, and in this regard they have adjusted their objectives to global EU strategy Europe 2020, which aspires to knowledge society.

A great number of indicators for monitoring the model of competitiveness, i.e. competitiveness indices, have appeared to monitor the degree of achievement the objectives of these strategies, the level of market development, and the level of competitiveness of national and regional economies at the end of the $20^{\text {th }}$ Century. However, while strategies define clear objectives, the basic problem is the selection of appropriate indicators, which should show the degree of achievement of the set strategies, as well as monitoring and controlling the set objectives.

The fundamental objective of this article is to create a new model for evaluation of knowledge competitiveness of nations. It is particularly important to identify those indicators in the model functioning that contribute, as well as those that reduce the quality of monitoring in the area of knowledge. The position of selected countries has been analyzed, and it represents one of the main results of our research. The study also includes regional level, involving Vojvodina in the analyses.

According to the analysis of the existing models for monitoring national competitiveness, the basic hypothesis of work is set: A new model of competitiveness, based on knowledge and predominantly quantitatively expressed parameters, provides a more realistic evaluation of the competitiveness of a country. The sub-hypothesis of the research is set as follows: We can identify certain groups of parameters (subindices) where the differences between the best and the worst ranked country are small, as well as those groups of parameters where these differences are significant. Testing each of the assumptions requires examination of the model structure, relations of individual parts and their functioning. Mathematical and statistical methods were used for quantitative relations within the model structure and in relations of model with other defined phenomena.

\section{Conceptual Background}

It could be argued that economic development has always been based on knowledge. However, the scope and the importance of knowledge for economic processes have fundamentally changed over the past few years [20]. What has changed in comparison to the old, traditional economics is that productivity growth, driven by technological and organizational innovation, has become a key source of economic growth. With concern about the environment, the restrictions 
on the use of natural resources are becoming more obvious. The source that enables overcoming that is the knowledge and the creation and linking of knowledge that supports the development of new commercial products and services [16].

"Knowledge society" as a term was first used by Drucker in 1969 [8], and its current meaning was accepted in the last decade of the $20^{\text {th }}$ Century. Drucker describes the knowledge society as a society of mobility and considers it to be the most competitive society in the history of mankind [9]. The OECD (1996) defines a knowledge-based economy as one in which the production, distribution and use of knowledge are the main drivers of growth, wealth creation, and employment for all industries [22].

The criteria of knowledge society are a high percentage of highly educated population, large government investments in education, science and research, encouragement of lifelong learning, high-quality and accessible information and communication infrastructure and services, propulsive and competitive economy, sustainable technological development, wide availability of information and easy access to them. Comparison of development of different national economies based on knowledge is made by evaluations of international organizations, state institutions, statistical departments and other institutions in collaboration with scientists [9]. Different authors and schools that have defined a number of indices related to competitiveness, which merged groups of various sets of criteria, emerged at the end of the $20^{\text {th }}$ and beginning of the $21^{\text {st }}$ Century. Organizations such as the World Economic Forum (WEF) and the Institute for Management Development publish rankings of national competitiveness among countries every year. These rankings are used as benchmarks for national policy makers and other interested parties in the evaluation of their countries in various fields [21]. There are several studies examining competitiveness indices including innovations, knowledge and technological progress [23, 22, 15, 20].

The number of indices that describe the competitiveness of knowledge today is considerably higher. We examined 23 composite indices, which define competitiveness of an economy, including the parameters of knowledge. It was noticed that they can be classified into the following four categories $[17,18]$ :

- competitiveness indices

- knowledge competitiveness indices

- innovation competitiveness indices

- information and communication technologies competitiveness indices

In order to closely follow the progress of European countries in transition, i.e. degree of fulfilment of the objectives set in the strategy of development until 2020 and on, it is necessary to set up a new, revised model, which will better indicate specific problems, the so-called bottlenecks in the development towards achieving the status of knowledge society. The key parameters of this new model are knowledge, innovation, R\&D, education, the use of IT technology, the development of knowledge-intensive jobs and sustainable development. 


\section{Methodology}

This research used calculating the average values, processing of time series, regression and correlation analysis. Results of the research are presented in analytical tables and charts. Secondary data, mainly official statistical reports and publications of prominent institutions, were also used as inputs in this phase of the study. The model used in this article is based on the manual establishment of thematic indicators. Constructing the composite indicator includes several stages. This model consists of nine steps:

1. Development of the conceptual framework;

2. Selection of data (indicators) and the sample size;

3. Transformation of irreversible data and replacing missing data;

4. Classification of indicators by thematic groups;

5. Standardization of individual indicators and assigning weight coefficients;

6. Aggregation and formation of thematic indicators;

7. Weighting of thematic indicators;

8. Aggregation and formation of competitiveness index;

9. Testing the competitiveness index.

It is important to mention that this process should not necessarily be seen as a sequential, and in many cases these steps are simultaneously taken [4].

\section{Data and Results}

\subsection{Development of the Conceptual Framework}

The framework for establishing a composite indicator as a summary of the phenomenon should provide a clear definition of what is to be measured and demonstrate which individual indicators should be sought and weighted [20]. The model presented and used in this article describes the state of an economy according to parameters of knowledge society in which general economic preconditions, the use of information and communication technologies, education, research and development, innovation and sustainable developmentare included. In [10] it is indicated that successful knowledge economies include factors such as long-term investments into education, sufficient innovation capacity, adequate information infrastructure and favourable economic surroundings. 


\subsection{Selection of Data (Indicators) and the Sample Size}

In the ideal case, variables should be selected on the basis of their analytical validity, measurability and relevance to the emergence of the indexation, rather than solely on the basis of data availability. In practice, the lack of necessary data is a frequent situation due to the fact that certain phenomena cannot be measured, or because no one has tried to measure them. Proxy measures can be used in this case, as a solution that should be adopted when there are problems of interstate comparability [16] However, using proxy measures means measuring something that is related to the phenomenon, but it is not the same as the phenomenon which is analysed. The selection of variables requires a balance between simplifying and complexity [4]. Scaling of variables with an adequate measure of size (e.g., population, income, land area, etc) is necessary in order to have an objective comparison between countries of different sizes.

\subsubsection{Selection of Indicators and Data Sources}

The model presented in the article contains 65 indicators which may be considered to represent the standards of knowledge-based society. It includes information about the state of the economy, the use of information and communication technologies, education, R\&D, innovativeness and sustainable development. Three out of 65 selected indicators represent mixed indicators (already measured composite indicators), the remaining are quantitative. By analyzing the existing models, it was found that the choice of larger number of parameters with the use of quantitative indicators makes composite index more objective. Qualitative parameters are subject to manipulation because they depend on assessors' subjective opinions. For this reason they are not included in the model developed in the article. However, a great deal of potentially very impactful parameters are not used because of this limitation.

1. Political stability and absence of violence is a composite indicator measuring probability that the government will be destabilized or overthrown, in an unconstitutional or violent way, including politically motivated violence and terrorism. Source: World Bank, The Worldwide Governance Indicators, (http://info.worldbank.org/governance/wgi/index.asp, 2012);

2. GDP per capita is gross domestic product divided by the number of inhabitants of middle age, in \$ 1000. Source: World Bank, (http://data. worldbank.org/indicator/NY.BDP.PCAP.CD?display=default, 2012);

3. Time required to start a business is the average duration in days required to complete all the procedures with a minimum subsequent additional obligations and payments. Source: World Bank, (www.doingbusiness.org, 2012);

4. Time needed for export is the period in days required to complete all the necessary procedures for export of product. Source: World Bank, (www.doingbusiness.org, 2012); 
5. Time needed for import is the period in days required to complete all the necessary procedures for import of product. Source: World Bank, (www.doingbusiness.org, 2012);

6. Percentage of households that use the internet. Source: Eurostat survey on ICT use by households or individuals, (http://epp.eurostat.ec.europa.eu/cache /ITY_SDDS/FR/isoc_bde15c_esms.htm, 2012), ITU, UN specialized agency for ICT, (www.itu.int/ITU-D/ict/statistics/, 2012);

7. Percentage of population that use the internet;

8. Percentage of households with high speed internet (with a flow rate not less than $100 \mathrm{Mb} / \mathrm{s}$ );

9. Percentage of population with high speed internet. Source for 6, 7, 8, and 9: Eurostat survey on ICT use by households or individuals, (http://epp.eurostat.ec.europa.eu/cache/ITY_SDDS/FR/isoc_bde15c_esms.htm ITU, UN specialized agency for ICT, www.itu.int/ITU-D/ict/statistics/, 2012);

10. Percentage of population that uses internet every day;

11. Percentage of population that uses internet once a week. Source for 10 and 11: Eurostat survey on ICT use by households or individuals, (http://epp.eurostat.ec.europa.eu/cache/ITY_SDDS/FR/isoc_bde15c_esms.htm );

12. The use of Facebook, as the number of users as percentage of population;

13. The use of Facebook as the number of users as on-line users is measured by the Socialbakers Company, (Source for 12. and 13: http://www.socialbakers.com/facebook-statistics/);

14. Video uploads on YouTube - number of video clips on YouTube measured for a population of 15 to 69 years of age. Source: Global Innovation Index, 2012;

15. Wikipedia, monthly editing on $\mathbf{1 0 0}$ internet users is measured on 100 Internet users. Source: Wikimedia Analysis on Information Flow, (stats.wikimedia.org, 2012);

16. The number of mobile telephony subscribers in relation to the population the number of subscriptions to a public mobile telephone service, which provides access to a public fixed network (PSTN) using mobile technology. Source: ITU, UN specialized agency for ICT, (www.itu.int/ITUD/ict/statistics/, 2012);

\section{Sophistication of service - citizens;}

18. Sophistication of service - companies - online sophistication is a measure of the level of development of government services. Source: European Commission, Digitizing of public services in Europe, 9 benchmark measurement 2009, European Commission, 2010; 
19. Active mobile broadband internet users per 100 inhabitants. Source: ITU, UN specialized agency for ICT, (www.itu.int/ITU-D/ict/statistics/, 2012);

20. Wikipedia - the percentage of share in total monthly postedcontent. Source: Wikimedia Traffic Analysis Report, (stats.wikimedia.org, 2012);

21. E-government - the percentage of citizens aged from 16 to 74 who use public services available online - the percentage of citizens who use e-government services (within last three months);

22. E-government - the percentage of companies who use public services available online. Source: Eurostat survey on the use of ICT and e-commerce in companies, Eurostat, 2010;

23. E-commerce - the percentage of population that orders goods or services via the Internet, Source: Eurostat survey on the use of ICT by households and individuals, (http://epp.eurostat.ec.europa.eu/cache/ITY_SDDS/FR/isoc_bde 15c_esms.htm);

24. Mobile phone services - the average cost per minute of different types of mobile calls (in PPP \$) are measured;

25. Rates for fast internet - the payment of monthly subscriptions for fixed broadband Internet service is measured (PPP (Purchasing Power Parity) in \$). Source for 24 and 25: United Nations specialized agency for ICT, (http://www.itu.int/ITU-D/IKT/statistics/, 2012);

26. Percentage of highly educated population (30-34). Source: European Commission, Innovative List, Innovation Union Scoreboard, UNU-MERIT, 2010;

27. No. of students per 100000 inhabitants, ISCED Classification 5 and 6;

28. Percentage of graduate students in engineering, manufacturing and construction, in relation to total no. of graduate students. Source for 27 and 28: UNESCO Institute, within online statistical report, (www.stats.uis.unesco.org, 2012);

29. Faculty enrolment, percentage of the total number of secondary school graduates - ISCED Classification 5 and 6. Source: World Bank, World Development Indicators Online, (http://data.worldbank.org/indicator /SE.TER.ENRR, 2012);

\section{Percentage of students who study abroad;}

31. Percentage of enrolled PhD students within the total number of enrolled students, ISCED Classification, 6. Source for 30 and 31: UNESCO Institute, statistical report,(www.stats.uis.unesco.org, 2012);

32. Percentage of employees with ICT skills. Source: Eurostat Labour Force Survey, Eurostat, 2011a; 
33. No. of researchers on 1000 inhabitants - total., Source: UNESCO, (www.stats.uis.unesco.org, 2012);

34. PISA scale - reading;

35. PISA scale - mathematics;

36. PISA scale - science is based on generally accepted PISA testing programs of elementary school students. Source: OECD, (http://www.oecd.org/pisa/, 2012);

37. Percentage of rural population, Source: World Bank, (http://data. worldbank.org/indicator/SP.RUR.TOTL.ZS/countries, 2012);

38. Number of doctorates on 1000 inhabitants aged from 25 to 34, source: European Commission, Innovative List, Innovation Union Scoreboard, UNUMERIT, 2010;

39. Implementation phase of the first and second cycle of Bologna is an indicator of educational development in European countries;

40. Phase of external quality system - the qualification framework has been introduced in the Bologna agenda between 2001 and the 2003;

41. Implementation phase of te ECTS system - the European Credit Transfer System (ECTS) is student credit system, which is a measure of required students' work necessary to achieve certain outcomes;

42. Implementation phase of the diploma supplement. Source for 39, 40, 41, 42: Eurostat, The European Higher Education Area in 2012: Bologna Process Implementation Report, (Eurostat, 2012);

43. Participation of the ICT sector (manufacturing and services) in GDP;

44. Participation of the ICT sector (manufacturing and services) in total employment. Source: Eurostat evaluation based on Structural Business Statistics and national accounts statistics (http://epp.eurostat.ec.europa.eu, 2012);

45. ICT export services (percentage of total exports services). Source: International Monetary Fund, The Statistical Yearbook of Balance of Payments and Data Files, published by the World Bank, (http://data.worldbank.org/indicator/BX.GSR.CCIS.ZS/countries, 2012);

46. ICT export of products (percentage of total export of products). Source: UNCTAD database of the UN Conference on Trade and Development, published by the World Bank. (http://data.worldbank.org/indicator/ TX.VAL.IKTGODINEZS.UN?cid=GPD_31, 2012);

47. Percentage of employees with university education, aged from 15 to 64 years, compared to the total number of employees. Source: Eurostat, Labour market statistics, Eurostat, 2011a; 
48. Investment in research and development - percentage of GDP. Source: UNESCO Institute, www.stats.uis.unesco.org, 2012;

49. Export of knowledge - intensive services (percentage of total export of services). Source: UN Statistics Division, unstats.un.org, 2012;

50. Spending on tertiary (higher) education per student, percentage of GDP. Source: UNESCO Institute, regular online statistical report, (www.stats.uis.unesco.org, 2012);

51. Spending on education, as a percentage of GDP, Source for 49 and 50: UNESCO Institute, regular online statistical report, (www.stats.uis.unesco.org, 2012);

52. Percentage of creativity export of total percentage of services - sum of credits in EBOPS (classification of the extended payment balance services). Source: UNCTAD, Creative Economy Report, 2010;

53. Percentage of creativity export of total percentage of goods measures the technological competitiveness of the EU, i.e. ability to commercialize the results of research and development and innovation in the international markets. It also reflects the specialization of production by countries. Source for 51 and 52: UNCTAD, Creative Economy Report, 2010;

54. Percentage of export of services related to computers (percentage of commercial services). Source: The International Monetary Fund, Statistical Yearbook of Payment Balance and Data Files, World Bank, http://data.worldbank.org/indicator/TX.VAL.OTHR.ZS.WT, 2012);

55. High technology export (percentage of total export of goods). Source: World Bank (http://data.worldbank.org/indicator/TX.VAL.TECH.MF.ZS/countries ?display=default, 2012);

56. Employment in knowledge-intensive professions. Source: Eurostat, Labour Market Statistics, 2011;

57. Number of scientific publications per million inhabitants - SCI list. Source: Thomson Reuters (Scientific) Inc. Web of Science, Science Citation Index Expanded;

58. Number of academic and professional articles in journals;

59. Number of academic and professional articles in per million inhabitants. Source: The National Science Foundation, Science and Engineering Indicators, World Bank, (http://data.worldbank.org/indicator/IP.JRN.ARTC.SC/ countries?display=default, 2012);

60. Number of patent applications per million inhabitants. Source: World Intellectual Property Organization, World Intellectual Property Indicators, WIPO, 2011; 
61. The use of pure and nuclear energy in total consumption in percentages, Source: World Bank, (http://data.worldbank.org/indicator/EG.USE. COMM.CL.ZS, 2012);

\section{The price of electricity - households e/100kWh;}

63. The price of electricity - industry e/100kWh. Source: Eurostat, Indicators of Energy, Transport and Environment (Eurostat, 2011b);.

64. Greenhouse gas emissions in $\mathrm{CO}_{2}$ per capita, measured by the Information Centre Analysis of Carbon Dioxide, the Department of Ecological Sciences, Oak Ridge National Laboratory, Tennessee, USA, World Bank (http://data.worldbank.org/indicator/EN.ATM.CO2E.PC?display=default);

65. Energy consumption in $1000 \mathrm{kWh}$ per capita, measured by The International Energy Agency and Eurostat, Indicators of energy, transport and environment (Eurostat, 2011b).

\subsubsection{Selection, Size and Construction of the Sample}

Sampling in this article was conducted according to the data of statistical yearbooks of the analysed countries, the database of Eurostat, the European Commission, the World Bank, the ITU, the UNECO, as well as on the basis of other relevant studies dealing with the measurement of competitiveness. Research and data analysis was performed for the calendar year 2010. The new model of Competitiveness Index of the Knowledge Based Society has been created and applied to the Republic of Serbia, the other Western Balkan countries and selected countries in Europe. The Autonomous Province Vojvodina of the Republic of Serbia is listed in the comparison on the regional level. The selected territorial units are: Sweden (SE), Finland (FI), Switzerland (CH), Denmark (DK), Norway (NO), Germany (DE), Austria (AT), Slovenia (SI), Montenegro (MN), Hungary (HU), Croatia (HR), Romania (RO), Bulgaria (BG), Macedonia (MK), Albania (AL), Bosnia and Herzegovina (BA), Serbia (RS) and Vojvodina (VO).

This choice was made in order to test the index for countries with different levels of development and status in the EU (member states, accessing countries, candidate countries, potential candidate countries for EU membership, the member states of the European Economic Community), and all of them should fit into the future knowledge-based society of Europe.

\subsubsection{Transformation of Irreversible Data and Replacing of Missing Data}

For indicators of irreversible character $(3,4,24,25,3762,63$ and 64), in the sense that lower value indicates a higher level of development, it is necessary to make a transformation:

$\mathrm{Xtrans}=2 *(\mathrm{Xmax}-\mathrm{Xmin})-\mathrm{Xi}$

One of the fundamental problems in the selection of variables was lack of available and comparable data. In this article, we used the nearest neighbour 
method, on which basis values are complement according to estimate in respect of the most similar case.

\subsubsection{Classification of Indicators into Thematic Groups}

The 65 selected indicators are classified into six thematic subindices: General Preconditions, Using Advanced Technologies, Education, Research and Development, Innovation and Sustainable Development.

The General Preconditions subindex represents a conditional element of the knowledge-based society is the economic impact, consisting of items 1 to 5 from the list of indicators.

The Use of Advanced Technologies subindex. Effective communication, distribution, assimilation and development of ideas and knowledge are facilitated by providing a modern and adequate infrastructure. ICT are essential factor of the knowledge-based society. This subindex consists of items No. 6 through 25 form the list of indicators.

The Education subindex. Human capital refers to the well-educated and skilled workforce $[19,5,2]$. This subindex consists of indicators listed under numbers 26 to 42 .

The Research and Development subindex refers to the development of an effective innovation system in firms, research centres and other relevant organizations and institutions, which results in new goods, new processes and new knowledge. This subindex encompasses indices from 43 to 56.

The Innovation subindex consists of indices 57 to 60 .

The Sustainable Development subindex consists of indices 61 to 65 .

\subsection{Standardization of Individual Indicators and Weighting}

In order to avoid problems of mixing different measuring units they should be normalized or standardized. Different techniques can be used in this way, and each has its advantages and disadvantages and can produce different results [20].

To obtain average equal to 100 for all variables, the following conversion was applied:

$s_{i j}=\frac{x_{i j}}{\bar{x}_{j}} \cdot 100$

where:

$x_{i j}$ is value of the $j$-th indicator of indicator of the $i$-th state;

$S_{i j}$ is standardized value of the $j$-th indicator of indicator $i$-th of state; and

$\overline{\mathrm{x}}_{j}$ is 1 average value of the $\mathrm{j}$-th indicator. 
Variables that are used for construction of the competitiveness index must be weighted to reflect the importance, reliability and other characteristics of the basic data. A way to identify the appropriate weights is through empirical analysis, especially using methods based on correlations among the used variables (e.g. regional analysis, principal component analysis, factor analysis, etc.) [23]. However, it is not certain that the correlations will correspond to real connections between the measured phenomena [15]. Alternatively, the weights can be set up in cooperation with various interested parties (e.g., experts, creator of policies, etc.), on condition that they understand the strengths, weaknesses and peculiarities of data within a given theoretical framework or the weights can be assigned according to the quality and availability of data. Since different weighting techniques can produce quite different results, no weighting approach is safe tool of obtaining credible results. For this reason, in [3] it is argued that the same weighting should be the norm. In [4] this attitude is accepted on the basis of simplicity, in terms of composite construction and interpretation [20].

Compression of standard values using weights with the total sum of 1 was used to form corresponding subindices. Composite subindices were further weighted to form a common composite index. The structure of the composite index with weighting factors of its subindices is shown in Figure 1. This approach is different from [1, 4], because authors assigned different weight values based on their contribution. The highest weights were given to Using Advanced Technologies $(25 \%)$ and Education $(25 \%)$ because authors believe that these are groups of parameters that have the greatest influence on the development of the knowledge society and also these subindices contain the largest number of individual parametres. The General Precondition subindex consists of 5 indicators, and is weighted $20 \%$. The Political Stability parameter is weighted $30 \%$, while the remaining 3 got the value of weighting factor of $10 \%$.

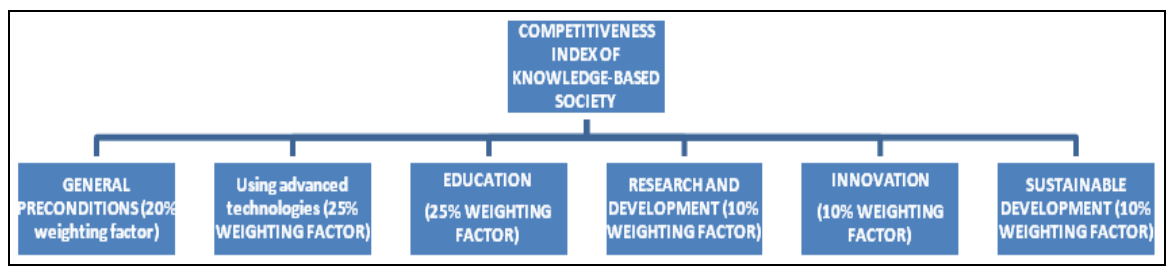

Figure 1

Competitiveness Index of Knowledge-Based Society

Table 1 shows the cumulative standardized and weighted values of parameters summarized in composite subindices. Assigning weight coefficients to subindices, as well as aggregation, i.e. adding the values of the composite subindices and the formation of the final composite index and ranking of countries and regions were carried out in the Table 2. 
Table 1

Composite subindices - standardized and weighted values and the composite index

\begin{tabular}{|c|c|c|c|c|c|c|}
\hline $\begin{array}{c}\text { Composi } \\
\text { te } \\
\text { subindic } \\
\text { es }\end{array}$ & $\begin{array}{c}\text { General } \\
\text { Precondi } \\
\text { tions } \\
\text { (GP) }\end{array}$ & $\begin{array}{c}\text { Using } \\
\text { Advanced } \\
\text { Technologi } \\
\text { es (AT) }\end{array}$ & $\begin{array}{c}\text { Educat } \\
\text { ion } \\
\text { (ED) }\end{array}$ & $\begin{array}{c}\text { Research and } \\
\text { Development } \\
\text { (RD) }\end{array}$ & $\begin{array}{c}\text { Innovation } \\
\text { (IN) }\end{array}$ & $\begin{array}{c}\text { Sustainable } \\
\text { Development } \\
\text { (SD) }\end{array}$ \\
\hline SE & 149.5 & 140.9 & 136.6 & 150.7 & 189.5 & 153.2 \\
\hline DE & 129.3 & 119.9 & 114.3 & 124.1 & 365.4 & 75.0 \\
\hline FI & 145.7 & 139.3 & 145.5 & 146.7 & 173.0 & 124.1 \\
\hline AT & 142.1 & 120.7 & 105.1 & 107.0 & 131.0 & 106.2 \\
\hline CH & 176.5 & 116.6 & 125.5 & 128.8 & 216.0 & 101.3 \\
\hline DK & 160.9 & 142.1 & 126.9 & 134.6 & 170.9 & 88.1 \\
\hline NO & 206.1 & 144.8 & 128.0 & 116.2 & 153.8 & 181.4 \\
\hline SI & 95.2 & 114.0 & 102.2 & 94.1 & 107.3 & 88.3 \\
\hline ME & 68.8 & 72.9 & 88.0 & 60.7 & 6.1 & 87.1 \\
\hline HU & 78.8 & 99.5 & 92.7 & 136.3 & 52.5 & 81.7 \\
\hline HR & 77.5 & 86.9 & 85.1 & 80.3 & 44.7 & 85.0 \\
\hline RO & 67.1 & 67.5 & 89.7 & 101.3 & 24.5 & 98.6 \\
\hline BG & 56.9 & 78.5 & 91.8 & 83.9 & 22.6 & 88.0 \\
\hline MK & 52.4 & 78.1 & 69.9 & 66.4 & 36.4 & 85.3 \\
\hline AL & 48.9 & 62.3 & 69.8 & 41.1 & 17.4 & 113.1 \\
\hline RS & 52.1 & 78.6 & 80.7 & 93.2 & 37.6 & 88.6 \\
\hline VO & 51.8 & 80.4 & 88.0 & 91.8 & 45.0 & 78.3 \\
\hline BA & 40.4 & 57.1 & 60.1 & 43.0 & 6.3 & 76.8 \\
\hline Sum: & 1800.0 & 1800.0 & 1800.0 & 1800.0 & 1800.0 & 1800.0 \\
\hline
\end{tabular}

Table 2

Composite index - assigning weight coefficients to subindices and aggregation and formation of the competitiveness index

\begin{tabular}{|c|c|l|l|l|l|l|l|c|}
\hline $\begin{array}{c}\text { Composite } \\
\text { subindices }\end{array}$ & GP & AT & ED & RD & IN & SD & $\begin{array}{l}\text { COMPO- } \\
\text { SITE } \\
\text { INDEX }\end{array}$ & RANK \\
\hline Weight & $\mathbf{0 . 2}$ & $\mathbf{0 . 2 5}$ & $\mathbf{0 . 2 5}$ & $\mathbf{0 . 1}$ & $\mathbf{0 . 1}$ & $\mathbf{0 . 1}$ & \\
\hline SE & 29.9 & 35.2 & 34.2 & 15.1 & 18.9 & 15.3 & 148.6 & $\mathbf{2}$ \\
\hline DE & 25.9 & 30.0 & 28.6 & 12.4 & 36.5 & 7.5 & 140.9 & $\mathbf{4}$ \\
\hline FI & 29.1 & 34.8 & 36.4 & 14.7 & 17.3 & 12.4 & 144.7 & $\mathbf{3}$ \\
\hline AT & 28.4 & 30.2 & 26.3 & 10.7 & 13.1 & 10.6 & 119.3 & $\mathbf{7}$ \\
\hline CH & 35.3 & 29.1 & 31.4 & 12.9 & 21.6 & 10.1 & 140.4 & $\mathbf{5}$ \\
\hline DK & 32.2 & 35.5 & 31.7 & 13.5 & 17.1 & 8.8 & 138.8 & $\mathbf{6}$ \\
\hline NO & 41.2 & 36.2 & 32.0 & 11.6 & 15.4 & 18.1 & 154.6 & $\mathbf{1}$ \\
\hline SI & 19.0 & 28.5 & 25.6 & 9.4 & 10.7 & 8.8 & 102.1 & $\mathbf{8}$ \\
\hline ME & 13.8 & 18.2 & 22.0 & 6.1 & 0.6 & 8.7 & 69.4 & $\mathbf{1 5}$ \\
\hline HU & 15.8 & 24.9 & 23.2 & 13.6 & 5.2 & 8.2 & 90.9 & $\mathbf{9}$ \\
\hline
\end{tabular}




\begin{tabular}{|c|c|c|c|c|c|c|c|c|}
\hline HR & 15.5 & 21.7 & 21.3 & 8.0 & 4.5 & 8.5 & 79.5 & $\mathbf{1 0}$ \\
\hline RO & 13.4 & 16.9 & 22.4 & 10.1 & 2.4 & 9.9 & 75.2 & $\mathbf{1 1}$ \\
\hline BG & 11.4 & 19.6 & 22.9 & 8.4 & 2.3 & 8.8 & 73.4 & $\mathbf{1 3}$ \\
\hline MK & 10.5 & 19.5 & 17.5 & 6.6 & 3.6 & 8.5 & 66.3 & $\mathbf{1 6}$ \\
\hline AL & 9.8 & 15.6 & 17.4 & 4.1 & 1.7 & 11.3 & 59.9 & $\mathbf{1 7}$ \\
\hline RS & 10.4 & 19.7 & 20.2 & 9.3 & 3.8 & 8.9 & 72.2 & $\mathbf{1 4}$ \\
\hline VO & 10.4 & 20.1 & 22.0 & 9.2 & 4.5 & 7.8 & 73.9 & $\mathbf{1 2}$ \\
\hline BA & 8.1 & 14.3 & 15.0 & 4.3 & 0.6 & 7.7 & 50.0 & $\mathbf{1 8}$ \\
\hline Sum: & 360.0 & 450.0 & 450.0 & 180.0 & 180.0 & 180.0 & 1800.0 & \\
\hline
\end{tabular}

According to the developed composite index of competitiveness of the knowledge-based society, Norway stands out as the first on the ranking list with 153.2 index points. It is followed by Sweden (149.3), Germany (147.7), Finland (144.9), Switzerland (141.3) and Denmark (138.4). Although located on the $7^{\text {th }}$ place, Austria has an above average number of points (117.7), while the eighth placed Slovenia represents an average ranking of countries with 95.5 index points. Hungary occupies the ninth place with 89.8 points. The Western Balkan countries (and the region of Vojvodina) have a similar number of scored points, and are ranked in the following order after Hungary: Croatia (78.6), Vojvodina (74.3), Romania (74.2), Serbia (72.9), Bulgaria (72.7) and Montenegro (69.3). Lowerranked countries in the Western Balkans are Macedonia (66.0), Albania (59.9) and Bosnia and Herzegovina (50.1).

\subsection{Testing the Composite Indicator}

As it has been already mentioned, there are several possibilities regarding the selection, standardization and aggregation of variables into one composite indicator. The results depend on the chosen approach. For this reason, sensitivity tests are conducted to analyse the impact of the inclusion or exclusion of different variables, change in weights, the use of different techniques of standardization, etc., on the results of the composite indicator. The combination of uncertainty and sensitivity analysis can be used to estimate the robustness of the composite indicator as well as for quality improvement. The uncertainty analysis examines how uncertainty is propagated within the input data through the structure of the composite indicator and affects its value, while sensitivity analysis evaluates the contribution of individual source of uncertainty to deviation of the final result. Composite indicators usually measure phenomena that are related to the wellknown and measurable concept (e.g. economic growth). These connections can be used for testing the strength of composite explanation. Common cross-plot method provides a good way to illustrate such connections. Correlation analysis is equally useful for testing, whereby high correlation indicates a composite indicator of high quality [20]. This article uses the methods of correlation, regression and variance. 


\subsubsection{Regression Analysis Based on the Indicators of Economic Dynamism}

The indicator of economic dynamism shows how GDP per capita affects the final result. The indicator is obtained in such a way that standardization of values of the composite index using the "minimum-maximum method" is first performed. This method transforms real values to values between zero (minimum value) and one (leader of the maximum value). This gives a picture of the distance of some country from the best and worst ranked state, i.e. common composite index compared to the difference between maximum and minimum.

The common composite index compared to the difference between maximum and minimum (yi) is calculated according to the formula:

$\mathrm{yi}=(\mathrm{Xi}-\mathrm{Xmin}) /(\mathrm{Xmax}-\mathrm{Xmin})$

where yi is the standardized value, $\mathrm{Xi}$ is the actual value, $\mathrm{Xmax}$ is the maximum value and $\mathrm{Xmin}$ is the minimum value.

Standardization as a method does not affect the ranking of countries for individual indicators. Indicators of economic dynamism (ECi) are:

$(\mathrm{ECi})=\operatorname{GDPi}(1+\mathrm{yi})$

where yi is a common composite index in relation to the difference between maximum and minimum, and GDPi per capita in USD thousands.

The obtained Indicator of Economic Dynamism is shown in Table 3 together with the Competitiveness Index of the Knowledge-Based Society. Ranks are assigned to the countries/regions in both situations. Rank type I refers to the classification of economies according to the Competitiveness Index of the Knowledge-Based Society and Rank type II on the results of Indicator of Economic Dynamism.

Table 3

Composite Competitiveness Index of the Knowledge-Based Society and indicator of Economic Dynamism - ranking of countries

\begin{tabular}{|c|c|c|c|c|c|c|}
\hline COUN & $\begin{array}{c}\text { The common } \\
\text { Composite } \\
\text { Competitive } \\
\text { ness Index of } \\
\text { the } \\
\text { Knowledge- } \\
\text { Based } \\
\text { Society }\end{array}$ & $\begin{array}{c}\text { RANK } \\
\text { type I }\end{array}$ & $\begin{array}{c}\text { The common } \\
\text { Composite } \\
\text { competitiveness } \\
\text { index in relation to } \\
\text { the difference } \\
\text { between maximum } \\
\text { and minimum }\end{array}$ & $\begin{array}{c}\text { Gross } \\
\text { domestic } \\
\text { product } \\
\text { per capita } \\
\text { in USD } \\
\text { thousands }\end{array}$ & $\begin{array}{c}\text { Indicator } \\
\text { of } \\
\text { Economic } \\
\text { Dynamism }\end{array}$ & $\begin{array}{c}\text { RANK } \\
\text { type II }\end{array}$ \\
\hline SE & 149.3 & $\mathbf{2}$ & 0.9623 & 48.9 & 96.0 & $\mathbf{4}$ \\
\hline DE & 147.7 & $\mathbf{3}$ & 0.9468 & 40.2 & 78.2 & $\mathbf{6}$ \\
\hline FI & 144.9 & $\mathbf{4}$ & 0.9197 & 45.1 & 86.5 & $\mathbf{5}$ \\
\hline AT & 117.7 & $\mathbf{7}$ & 0.6558 & 45.2 & 74.8 & $\mathbf{7}$ \\
\hline CH & 141.3 & $\mathbf{5}$ & 0.8849 & 67.5 & 127.2 & $\mathbf{2}$ \\
\hline DK & 138.4 & $\mathbf{6}$ & 0.8561 & 55.9 & 103.7 & $\mathbf{3}$ \\
\hline NO & 153.2 & $\mathbf{1}$ & 1.0000 & 84.5 & 169.1 & $\mathbf{1}$ \\
\hline SI & 99.5 & $\mathbf{8}$ & 0.4786 & 22.9 & 33.8 & $\mathbf{8}$ \\
\hline
\end{tabular}




\begin{tabular}{|c|c|c|c|c|c|c|}
\hline ME & 69.3 & $\mathbf{1 5}$ & 0.1861 & 6.5 & 7.7 & $\mathbf{1 2}$ \\
\hline HU & 89.8 & $\mathbf{9}$ & 0.3849 & 12.9 & 17.8 & $\mathbf{9}$ \\
\hline HR & 78.6 & $\mathbf{1 0}$ & 0.2765 & 13.8 & 17.6 & $\mathbf{1 0}$ \\
\hline RO & 74.2 & $\mathbf{1 2}$ & 0.2340 & 7.5 & 9.3 & $\mathbf{1 1}$ \\
\hline BG & 72.7 & $\mathbf{1 4}$ & 0.2189 & 6.3 & 7.7 & $\mathbf{1 3}$ \\
\hline MK & 66.0 & $\mathbf{1 6}$ & 0.1539 & 4.5 & 5.1 & $\mathbf{1 6}$ \\
\hline AL & 59.9 & $\mathbf{1 7}$ & 0.0948 & 3.7 & 4.0 & $\mathbf{1 8}$ \\
\hline RS & 72.9 & $\mathbf{1 3}$ & 0.2208 & 5.3 & 6.4 & $\mathbf{1 4}$ \\
\hline VO & 74.3 & $\mathbf{1 1}$ & 0.2345 & 5.0 & 6.2 & $\mathbf{1 5}$ \\
\hline BA & 50.1 & $\mathbf{1 8}$ & 0.0000 & 4.4 & 4.4 & $\mathbf{1 7}$ \\
\hline Sum: & 1800.0 & & 8.7087 & & & \\
\hline
\end{tabular}

\subsubsection{Analysis of the Range of Variation and Variance}

This analysis shows how big are differences between the top-ranked and lowestranked economy according to composite subindices. The standard deviation represents the average deviation from the average value. The coefficient of variation represents the quotient of the standard deviation and average value. Analysis results are presented in Table 4. Some groups of parameters have a greater range of variations, and other less. The difference between the Innovation and Education subindices is particularly significant. Namely, the difference between the best and worst ranked countries of 359.2 points within the subindex Innovation is measured. This result can be explained by conspicuous differences between Western countries and the Western Balkan countries in terms of the parameters that make this subindex. However, the analysis showed that these differences are not so significant within the Education and Using Advanced Technologies subindices. More than four times lower difference than within the Innovation subindex is measured within Education subindex, amounting to 85.4 points. Similar is with the Using Advanced Technologies subindex, for which this difference is 92 index points. The analysis of the coefficient of variance shows similar results. The coefficient of variation of $96.5 \%$, which expresses great differences within the analyzed countries in terms of this subindex measured within the Innovation subindex. On the other hand, the coefficient of variation of $24.65 \%$ was measured within the Education subindex, which shows significantly smaller differences between countries when it comes to this subindex. There is a long tradition in education in the Western Balkans territory, and this is the reason why these differences are less pronounced compared to Western European countries.

Table 4

Analysis of the range of variation and variance

\begin{tabular}{|l|c|c|c|c|c|c|}
\hline Composite subindex & GP & AT & ED & RD & IN & SD \\
\hline max & 40.36 & 57.73 & 60.10 & 41.14 & 6.12 & 75.03 \\
\hline min & 206.13 & 147.29 & 145.48 & 150.67 & 365.37 & 181.37 \\
\hline range of variation & 165.78 & 89.56 & 85.38 & 109.53 & 359.24 & 106.34 \\
\hline
\end{tabular}




\begin{tabular}{|l|c|c|c|c|c|c|}
\hline variance & 2701.58 & 1064.48 & 601.11 & 1112.18 & 9326.86 & 1080.04 \\
\hline standard deviation & 51.98 & 32.63 & 24.52 & 33.35 & 96.58 & 32.86 \\
\hline average value & 100.00 & 100.00 & 100.00 & 100.00 & 100.00 & 100.00 \\
\hline coefficient of variation & $51.98 \%$ & $32.63 \%$ & $24.52 \%$ & $33.35 \%$ & $96.58 \%$ & $32.86 \%$ \\
\hline
\end{tabular}

\subsubsection{Correlation Matrix of Composite Indicators}

The matrix (Table 5) shows the correlation of economic dynamism (ECD) with other subindices.

Table 5

Correlation matrix of composite indicators

\begin{tabular}{|l|l|l|l|l|l|l|l|}
\hline & ECD & GP & AT & ED & RD & IN & SD \\
\hline ECD & 1.000 & 0.986 & 0.872 & 0.855 & 0.686 & 0.752 & 0.685 \\
\hline GP & 0.986 & 1.000 & 0.898 & 0.895 & 0.741 & 0.764 & 0.647 \\
\hline AT & 0.872 & 0.898 & 1.000 & 0.921 & 0.843 & 0.892 & 0.489 \\
\hline ED & 0.855 & 0.895 & 0.921 & 1.000 & 0.880 & 0.758 & 0.575 \\
\hline RD & 0.686 & 0.741 & 0.843 & 0.880 & 1.000 & 0.700 & 0.369 \\
\hline IN & 0.752 & 0.764 & 0.892 & 0.758 & 0.700 & 1.000 & 0.251 \\
\hline SD & 0.685 & 0.647 & 0.489 & 0.575 & 0.369 & 0.251 & 1.000 \\
\hline
\end{tabular}

All relations that have a value above 0.7 are significant. According to the overview in Table 5, it can be concluded that the economic dynamism is associated with all the subindices except the Research and Development and Sustainable Development subindices, with which it is least consistent. The analysis of correlation is equally useful for testing, where high correlation indicates a composite indicator of high quality [20].

\section{Dilemmas and Reflections}

The Index of Competitiveness of the Knowledge-Based Society was calculated for 17 countries and one region, through standardization, weighting and aggregation. This choice was made in order to test the index for countries with different levels of development and status in the EU. Results showed that Serbia and Vojvodina are rated at about $75 \%$ of the average of the selected countries, and at the level of neighbouring EU countries and Croatia (which joined the EU in July 2013).

Testing of the composite index was conducted through the indicators of economic dynamism that show how Competitiveness Index of the KnowledgeBased Society depends on the parameters of GDP per capita. It was found that the differences between countries of Western Europe and the Western Balkans 
are dramatically higher when they are reflected through the GDP, as a representative indicator of economic development, than when this difference is measured in the parameters of knowledge.

The range of variations of different parameters is various. The difference between the Innovation and Education subindices is particularly significant. This result can be explained by prominent differences between Western countries and the Western Balkan countries in terms of scientific achievements which are reflected in the number highly qualified articles and in the patent applications. On the other hand, the difference within the Education subindex is measured more than four times lower compared to the subindex Innovation which amounts 85.4 points. It shows significantly smaller differences between countries when it comes to this subindex. Obtained results can be explained by the existence of a long tradition of education in the Western Balkan countries, and this is the reason why these differences are less pronounced compared to Western European countries. The sub-hypotheses of the article was accepted in this manner: Certain groups of subindices can be distinguished, where in some cases the difference between the best and worst ranked countries is small, as well as those groups of subindices where these differences are significant.

The authors of this article were in dilemma, that is, how to substitute for the missing data. They have chosen not to use qualitative data, but at the expense that there are some non-described fields due to lack of data. For that reason, some proxy data are used. Although a large number of quantitative data was used, as many as 65 , the dilemma was whether it was enough, that is, whether using more data it would provide even better results. The authors have chosen this number for practical reasons, i.e. availability of data. This dilemma leads to the appointment of a hypothesis for future research: with improved data availability, it is possible to describe knowledge-based society.

It is also very important to follow the trends of knowledge-based society and constantly adapt methodologies in this direction, by creating new and rejecting unnecessary parameters that describe the knowledge-based society. So, it would be suitable, for example, to include into future research the indicator of Percentage population who uses smartphones or the indicator Percentage of smart TVs in households. Besides, it is always necessary to analyze the importance of each and every group of parameters (subindices), in order to perform an adequate allocation of weighting factors. Also, during the standardization and transformation of data, it is possible to apply several methods, and it is necessary to consider whether the selected one is appropriate.

\section{Conclusion}

The main goal of this article was to create a new model for estimating the national knowledge competitiveness, whose implementation would help to achieve improvement the quality of monitoring in this area. It was found that Serbia and other countries in transition are not analysed adequately when in terms of the competitiveness of knowledge, that the existing indices analysing 
Serbia do not provide enough information about the state of development of knowledge in Serbia, and that Serbia is at the very bottom when compared to European and countries worldwide. It was also noticed that the existing models of knowledge contain a large number of qualitative indicators, which are subject to manipulative influences of experts, while models based on quantitative indicators consists of a small number of parameters. This is why it was concluded that the existing models of competitiveness that contain parameters of knowledge are not suitable for countries in transition like Serbia.

The results of this paper can be used primarily for adjustment of existing and development of new strategies, which accompany the European, national and regional documents. The results are also applicable for the identification of negative trends in regional development and its balancing. Paper also contributes to easier control of the set goals, discover reasons continuous low ranking of Serbia, and draw conclusions for strategic development planning.

It was suggested that a new, revised model should be set for successful monitoring of progress and the degree of achieving the goals set in strategies of development of European countries and Serbia until 2020. The basic hypothesis of the work is accepted: The new competitiveness model based on knowledge and predominantly expressed quantitative parameters gives a more realistic evaluation of competitiveness of a country.

Developing models of competitiveness often entails various difficulties. In the efforts to include as many indicators that describe the desired phenomenon, many authors face the problems of data collection and the lack of data for individual countries and regions. In that case, some authors try to insert qualitative indicators or assessments, which could lead to manipulation with the results by subjective evaluations.

Hopefully this paper has special importance for scientific and research workers studying fields related to knowledge and knowledge competitiveness. The range of this article can be expanded in further research. Taking a sample that would include all the European countries, more relevant comparison and ranking of economies could be made. Besides, future multi-annual monitoring of the competitiveness, according to the model developed in the article, would allow tracking of progress and growth rate of overall results and the individual parameters and groups of parameters for selected countries. The possibility that also occurs for future researchers is calculation of the Competitiveness Index of the Knowledge-Based Society for European regions. Significant results could also be obtained by sensitivity analysis of individual parameters and groups of parameters on the overall index result, which would contribute to making adequate conclusions and guidelines from the research.

\section{References}

[1] Babbie E. (1995), The Practice of Social Research. Wadsworth, Belmont

[2] Barro, R., Sala-i-Martin, X. (1995), Economic Growth. McGraw-Hill, New 
York. Chs. 1-4

[3] Baylis J., Smith S., The Globalization of World Politics, An Introduction to International Relations (New York: Oxford University Press, 1999), p. 15

[4] Booysen F. (2002), An Overview and Evaluation of Composite Indices of Development. Soc Indic Res 59:115-115

[5] Brunetti A. (1997), Political Variables in Cross-Country Growth Analysis. J of Econ Surv 11(2):163-190

[6] Chen D. H. C., Dahlman C.J. (2005), The Knowledge Economy, the KAM Methodology and World Bank Operations. World Bank Institute Working Paper no. 37256

[7] Daugèlienè R. (2006), Towards Knowledge-Based Economy: Modelling Knowledge Expression Assessment. European Union Enlargement of 2004 and Beyond: Responding to the Political, Legal and Socio-Economic Challenges, 451-469

[8] Drucker P. (1969), The Age of Discontinuity. Guidelines to Our Changing Society. Harper and Row: New York

[9] Drucker P. (2006), My View of Management - Ideas that Have Improved Management. Novi Sad: Adizes (In Serbian)

[10] European Commission (2010), Digitizing Public Services in Europe: Putting Ambition into Action, $9^{\text {th }}$ Benchmark Measurement, Capgemini, IDC, Rand Europe, Sogeti and DTi, European Commission, Directorate General for Information Society and Media

[11] Eurostat (2010), Internet Use in Households and by Individuals in 2010, Eurostat

[12] Eurostat (2011 b), Energy, Transport and Environment Indicators, Eurostat

[13] Eurostat (2011a), European Union Labour Force Survey, Eurostat

[14] Eurostat (2012), The European Higher Education Area in 2012: Bologna Process Implementation Report, ISBN 978-92-9201-256-4, Eurostat

[15] Freudenberg M. (2003), Composite Indicators of Country Performance: a Critical Assessment. OECD Science, Technology and Industry Working Papers, 2003/26, OECD Publishing, Paris

[16] Huggins R. and Izushi H. (2007), Competing for Knowledge, Creating, Connecting, and Growing, Routledge, New York

[17] Katić A., Ćosić I., Anđelić G., Raletić S. (2012), Review of Competitiveness Indices that Use Knowledge as a Criterion, Acta Polytechnica Hungarica 9(5):25-45, ISSN 1785-8860

[18] Mankiw N., Romer D., Weil D. (1992), A Contribution to the Empirics of Economic Growth. Q J Econ 107(2):407-437 
[19] Nardo M., Saisana M., Saltelli A., Tarantola S., Hoffman A., Giovannini E. (2005), Handbook on Constructing Composite Indicators: Methodology and User Guide. OECD Statistics Working Paper CTD/DOC(2005)3, OECD, Paris

[20] Nijkamp P., Siedschlag I. (2011), Innovation, Growth and Competitiveness, Dynamic Regions in the Knowledge-Based World Economy, Springer Heidelberg Dordrecht London New York

[21] Önsela S., Ülengina F., Ulusoyb G., Aktaşc E., Kabakc O., Topcuc Y. (2008), A new Perspective on the Competitiveness of Nations. SocioEconomic Planning Sciences. 42(4): 221-246

[22] Organisation for Economic Cooperation and Development (OECD). (1996), The Knowledge-Based Economy. Paris: OECD

[23] Porter M., Stern S. (1999), The New Challenge to America's Prosperity: Findings from the Innovation Index. Council of Competitiveness, Washington DC

[24] Saisana M. et al. (2005), State of the Art Report on Composite Indicators for the Knowledge-Based Economy. Deliverable 5.1 of the WP5 of the KEI project

[25] UNU-MERIT (2010) Innovation Union Scoreboard, The Innovation Union's Performance Scoreboard for Research and Innovation, Maastricht Economic and Social Research and Training Centre on Innovation and Technology (UNU-MERIT). www.proinno-europe.eu/metrics

[26] www.itu.int (2012), International Telecommunication Union

[27] www.oecd.org/pisa/ (2012) OECD Programme for International Student Assessment (PISA)

[28] www.sr.wikipedia.org (2012), Wikipedia

[29] www.stats.uis.unesco.org (2012), UNESCO Institute for Statistics

[30] www.stats.wikimedia.org (2012), Wikimedia Statistics

[31] www.tempus.ac.rs (2012), Kancelarija Tempus fondacije

[32] www.theatlantic.com (2012), Magazine Atlantic

[33] www.unstats.un.org (2012) United Nations Statistics Division 